\title{
USING THE BUSINESS ENGINEERING APPROACH IN THE DEVELOPMENT OF A STRATEGIC MANAGEMENT PROCESS FOR A LARGE CORPORATION: A CASE STUDY
}

\author{
CM Moll \\ PS Kruger \\ Department of Industrial and Systems Engineering, Faculty of Engineering \\ University of Pretoria
}

\begin{abstract}
Most South African organisations were historically part of a closed competitive system with little global competition and a relatively stable economy (Manning: 18, Sunter: 32). Since the political transformation, the globalisation of the world economy, the decline of world economic fundamentals and specific challenges in the South African scenario such as GEAR and employment equity, the whole playing field has changed. With these changes, new challenges appear. A significant challenge for organisations within this scenario is to think, plan and manage strategically. In order to do so, the organisation must understand its relationship with its environment and establish innovative new strategies to manipulate; interact with; and ultimately survive in the environment. The legacy of the past has, in many organisations, implanted an operational short-term focus because the planning horizon was stable. It was sufficient to construct annual plans rather than strategies. These plans were typically internally focused rathẹr than driven by the external environment. Strategic planning in this environment tended to be a form of team building through which the various members of the organisation's management team discussed and documented the problems of the day. A case study is presented of the development of a strategic management process for a large South African Mining company. The authors believe that the approach is a new and different way of addressing a problem that exists in many organisations - the establishment of a process of strategic thinking, whilst at the same time ensuring that a formal process of strategic planning is followed in order to prompt the management of the organisation for strategic action. The lessons that were drawn from this process are applicable to a larger audience due to the homogenous nature of the management style of a large number of South African organisations.
\end{abstract}




\section{Introduction}

The net effect of changes in the business environment has been that many organisations saw a necessity for some form of transformation or renewal in order to stay relevant in its competitive environment. Many South African companies, including the mining company discussed in this case study, have in the past five years embarked on a process of reengineering with varying levels of success. The inevitable question after the successful completion of a corporate reengineering process is what will the organisation be doing in future to avoid the need for further reengineering, or as in the case of most organisations, to avoid further downsizing. This is not merely a rhetorical question; it is a question that is asked by responsible management. The response to such a question is twofoid:

- Firstly, through an operational or short-term focused response by establishing a process of continuous improvement in the organisation that ensures competitiveness against other organisations who will undoubtedly also renew and improve themselves. It is an economic fact that the real prices and hence real revenues of most products or services decline over time therefore organisations need to improve themselves at a rate that stays congruent with these changes.

- Secondly, through a strategic or long-term response by establishing a process of strategic management in the organisation that ensures a holistic understanding of, and interaction with the business environment over the long-term.

It is stressed that both of these processes should be present in order for an organisation to be competitive. If an organisation only focuses on the process of continuous improvement, discontinuities over the long-term will not be addressed. Similarly, if an organisation only focuses on the strategic management process, short-term performance might become critical if not addressed properly. Upon investigation of these two imperatives it was found that no formal process, and hence no formal capability existed within the company discussed here in relation to these imperatives. Various informal processes and a vast amount of intelligence existed on them but their application was limited. Also, the particular company was at a watershed in terms of its long-term intent because various growth opportunities existed within this supposed environmental turbulence. This article discusses how the second imperative, that of strategic management, was addressed through the application of a Business Engineering approach. 


\section{Objective}

The objectives of this article are threefold:

- To demonstrate how the use of a Business Engineering approach can contribute towards the development of a strategic management process for an organisation;

- to present and discuss the model that resulted form this process; and

- to discuss the key lessons that were learnt in the process.

\section{Problem statement}

The mining company that is studied has undergone a major transformation process over the past three years. The results of this process were firstly that the organisation's operational performance has improved fundamentally relative to international'standards, secondly, a performance-driven culture was established and thirdly, an overall long-term intent was established. Whilst this overall long-term intent is an essential part of strategy, its pursuit was vague as various options existed to achieve this intent.

This long-term intent of the company is based on three fundamental goals. These goals are:

- To maximise the value that is created from current operations;

- to apply the proceeds of current operations to pursue a growth strategy; and

- to establish and nurture the skills that are required to achieve the previous two goals.

In its strife to achieve these goals, the company encountered various problems and opportunities that either enhanced or constrained the attainment of the long-term intent. No formal process existed to address these issues.

The mining industry is subject to commodity cycles which require industry foresight (Prahalad and Hamel: 27,28,29) and a strategic view of the marketplace. Decisions that are made have a long-term effect and correspond with large capital layouts that lock companies in to specific technologies and skills. Once decisions are made, resources (technology, people and capital) are allocated to a chosen option and other possible opportunities can not be pursued because resources are not available any longer. These two factors make it a necessity that thoughtful attention is given to strategic thinking and strategic decision-making. Upon investigation, the following conclusions were made regarding strategic management in the organisation:

- Strategic management was not a key organisational capability; 
- the corporate governance regarding strategic management was undefined resulting in a lack of role clarity between the corporate centre, the business units and the mines;

- the strategic management activities that did occur, including long-term planning, budgeting and performance measurement were not integrated or aligned;

- very little was done to investigate the external environment of the organisation in a formal, methodical way;

- the existing processes were largely aimed at business planning and budgeting rather than strategic thinking; and

- there was a strong commitment from senior management in the company to ratify this supposed lack of strategic management.

Ackoff $(1,2)$ describes the extreme of these observations as follows:

"A good deal of corporate planning I have observed is like a ritual rain dance; it has no effect on the weather that follows, but those who engage in it think it does. Moreover, much of the advice and instruction related to corporate planning is directed at improving the dancing, not the weather."

Approach

\subsection{Business Engineering approach to strategic management}

The application of a Business Engineering approach (Moll: 22,23) for the development of a strategic management process for an organisation is twofold:

- Business Engineering provides a methodical procedure for the analysis, design, implementation and maintenance of business solutions. Its first application is thus based on the use of the method as a practitioner's tool to investigate and improve the processes of an organisation. The strategic management process of an organisation is. like the name indicates, a business process that can be analysed, designed, implemented and maintained.

- Business Engineering provides a template of objects that can be employed in the strategic management process. In strategic management, in a similar fashion to Business Engineering, the business environment is investigated and a strategy is designed, implemented and executed.

Business Engineering can be viewed as a parent discipline to strategic management, in the same way as Management Theory is considered such. Whereas strategic management processes have been developed in many organisations using the principles of Management Theory, the application of Business Engineering is new and different. Management Theory is often more concerned with debating and understanding the 
academics and ideologies of management per sé. Whereas Management Theory provides a sound basis of understanding the behavioural, leadership-related and management issues involved in strategy, it does not focus deliberately on the establishment of a structured and systematic process, nor does it strive to integrate the elements of the process. These tenets are the main focus areas of Business Engineering and distinguish it from other approaches. Like with any approach, it takes a perspective on a specific topic. In doing so, certain elements are more visible than with any other approach whilst other elements are obscured.

The relationships between Business Engineering, Strategic Management and Management Theory are shown in figure 1 .

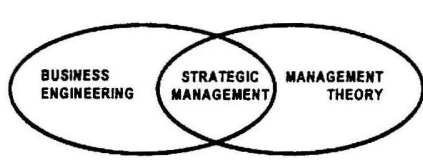

Figure 1 - Relationship between Business Engineering, Strategic Management and Management Theory

\subsection{The Business Engineering approach}

\subsubsection{Background}

Ackoff $(1,2)$ suggests that various new disciplines are emerging in the world today, distinguishing themselves by having different perspectives on existing phenomena. This is the result of a move towards a more systemic way of understanding and influencing the environment. He writes as follows on these emerging disciplines:

"Unlike traditional scientific disciplines which seek to distinguish themselves from each other and to spin off new disciplines when new areas of interest develop within them, the new inter-disciplines seek to extend themselves and merge with each other, to increase the number of disciplines they incorporate and to enlarge the class of phenomena with which they are concerned. Even these inter-disciplines are seen as part of a still larger whole, the systems sciences."

Various new approaches have been introduced to the business world in the past two decades, mostly as a result of the turbulent and exponential nature of the business environment. These approaches vary form Business Process Reengineering $(5,8,9,12,12)$, 
Benchmarking $(6,7)$, Theory of Constraints $(10,11)$, Total Quality Management approaches (14) and the like. Whilst the theories behind these approaches are generally sound and logical, they tend to create an amount of confusion in the business environment because they overlap and tend to remove the focus of organisations from thinking fundamentally about their business. This confusion is aggravated by the fact that these approaches come neatly packaged and skilfully marketed by consultants from an industry that has grown considerably in the past decade. Also, they are presented in a complex and sophisticated way, which removes the focus from their fundamentals. When teaching children mathematics, the focus starts with the fundamentals and the more complex methods are eventually constructed from these. In business transformation however, the opposite process is forced upon organisations.

This difference is shown in figure 2.

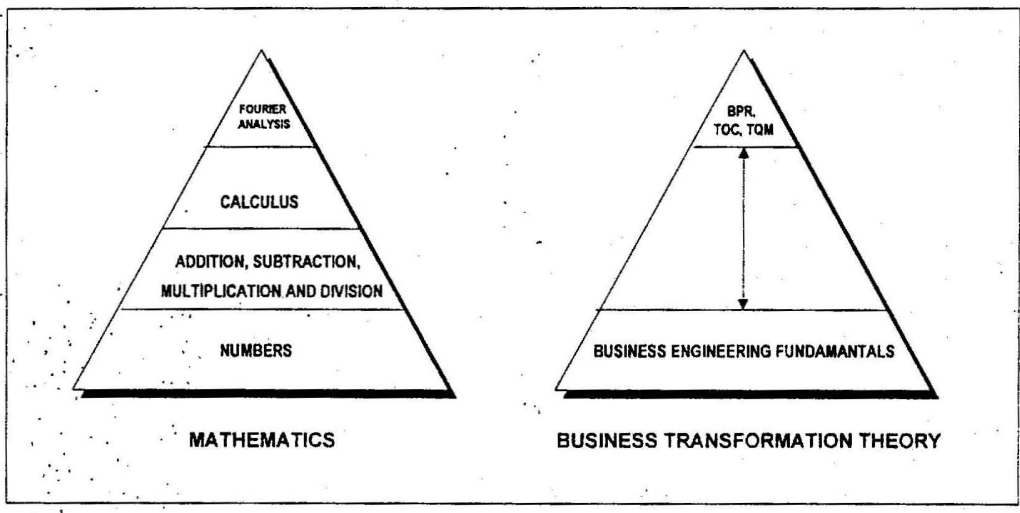

Figure 2 - Fundamentals of Mathematics and Business Engineering $\therefore$.

The subject area of Business Engineering has been defined in an effort to describe and position the full set of approaches required to optimise or improve the performance of organisations. It is an effort to define a theoretical home for the various business transformation related theories and approaches.

Business Engineering is defined by Moll and Bosman $(22,23)$ as the subject area that aims to develop or redevelop an organisation based on the application of an engineering thought process and sound business principles. Business, in this context, is defined as all efforts aimed at the sustained creation of wealth for all the stakeholders of an organisation. 


\subsubsection{Business Engineering Process}

In Business Engineering a systems view is taken of the development or redevelopment of an organisation. This Business Engineering approach is based on the process shown in figure 3 .

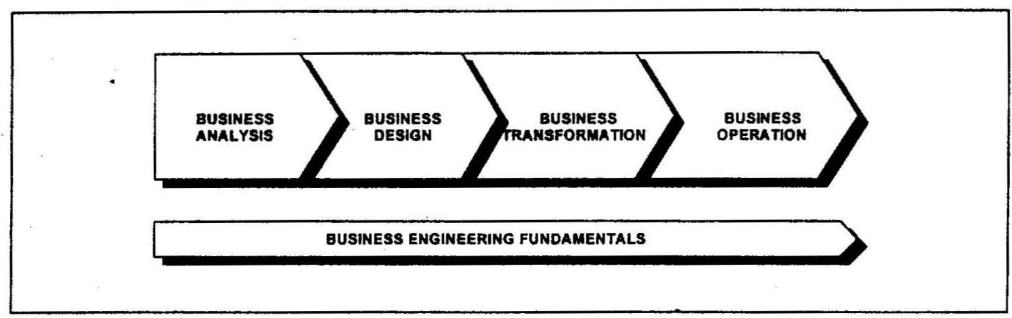

Figure 3 - The Business Engineering Process

\subsubsection{Properties of the Business Engineering Process}

The Business Engineering Process has the following three properties:

- It is an object-based approach. Objects are the building blocks that are used to develop specific approaches to specific problems. It is not suggested that the complete process be applied to every specific business transformation initiative. In conducting a business transformation study, the scope of the problem and the requirements at hand will necessarily have to be determined. A fifth phase in the Business Engineering Process, termed the initiation phase, is therefore implied. After the scope has been determined, a selection can be made of the objects required for the transformation process. These objects are subsets of the phases of the process. Using the process as a framework, the relevant objects can thus be assembled in such a way as to develop a strategic management process.

- It provides for cross-functional business transformation models because it is an integrated approach. Therefore, various related processes that are aimed at business transformation can be derived by using specific configurations of these objects. A strategic management process is an example of this. This cross-functional process of strategic management is shown in figure 4 . 


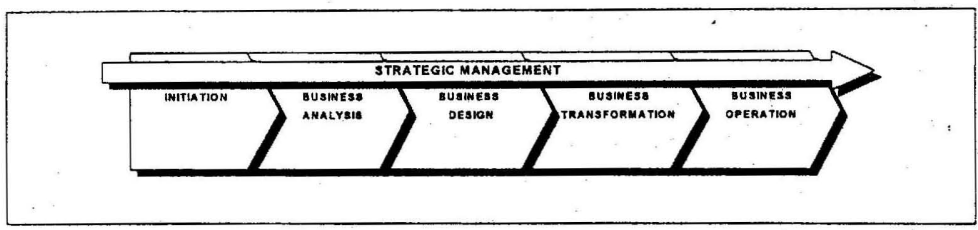

Figure + -Strategic management as a cross-functional Business Engineering process

- It is a fundamental approach. The approach was constructed from basic principles. The application of these principles provides a generic framework that can be applied to various problems and can be used to develop specific approaches to problems.

\subsection{Strategic Management}

\subsubsection{Fundamentals of Strategic Management}

Strategic Management, as the name implies, is all about strategy. A strategy or strategic plan forms the blueprint for the long-term direction of an organisation by defining three imperatives:

- How the organisation intends to manage the influence of the external environment;

- what the future intent is within the business environment and how this will be achieved; and

- what the future intent is within the internal environment and how this will be achieved.

In order to define the strategic management process of an organisation the term strategic ${ }^{\circ}$ must be understood.

"STRATEGY - generalship...the art of formulating a series of manoeuvres to obtain a specific goal."

\section{Oxford Dictionary}

The term strategy or its adjective strategic, was derived from the Greek word stratos, meaning army or war. As much as society claims to be civilised, people will always engage in warfare. The reason for warfare is simple - a common goal that is pursued by two or more opposing parties. Although the basis for warfare in the business environment is economic interaction between the organisation and its stakeholders, the 
philosophies around strategy remains the same as those proposed for warfare by the Chinese 2000 bC (Sun-Tzu: 31).

"Warfare is the greatest affair of state, the basis of life and death, the way to survival and extinction. It must be thoroughly pondered and analysed."

\section{Sun Tzu in "The Art of War"}

-A strategy specifies the thinking of the general, describes the proposed course of action of the different campaigns that compose the war and regulates the battles to be fought in each.

A number of strategy theorists have attempted to define the generic strategies an organisation can follow. Ansoff $(3,4)$ proposes four generic strategy types:

- Market penetration;

- product development;

- market development; and

- diversification.

Porter $(24,25,26)$ proposes three generic focus areas in strategy namely cost competitiveness (being as cost effective as possible), product differentiation (focusing on product and service quality) or focused niche (focusing on stakeholder requirements not addressed by : other organisations).

These basic focus areas are shown in table 2.

\begin{tabular}{lll}
\hline FOCUS AREA & COST & DIFFERENTIATED \\
& COMPETITIVENESS & . COMPETITIVENESS \\
\hline INDUSTRYWIDE & cost leadership strategy & Differentiation strategy \\
\hline MARKET SEGMENT & focus strategy & Focus strategy \\
\hline
\end{tabular}

Table 1 - Strategic focus areas in an organisation

The value disciplines as proposed by Treacy and Wiersema $(33,34)$ is a generalisation of these by suggesting that an organisation can choose one of three strategies namely customer intimacy, product leadership or operational excellence.

The authors propose that a generalised model be used consisting of the following generic strategies:

- Vertical integration of the business system through the formation of alliances, mergers and acquisitions; 
- consolidation through the outsourcing of investments that can be managed effectively and efficiently elsewhere;

- diversification through the addition or removal of investments;

- development and growth through mergers and acquisitions or expansions of existing investments;

- restructuring through optimising the performance of the organisation; and

- resource optimisation through the improvement of resource productivity.

\subsubsection{The strategic management process}

When investigating the process of strategic management, it is necessary to understand the difference between strategic planning as defined by Ansoff $(4,5)$ and strategic thinking as defined by Mintzberg $(19,20)$. The former refers to the formal process in the organisation of compiling long-term and short-term plans and implementing them, the latter refers to the skill associated with the strategic management process.

Strategic thinking ensures the effectiveness of the process - that the organisation is focused on the relevant issues. Strategic planning is concerned with the efficiency of the process - the level of success with the execution of the formal process. It is therefore important to recognise that, while the strategic management process is focused on this formal process, this is not an ultimate measure of success. Mintzberg (21) was the first to recognise these differences.

\subsubsection{Strategic governance}

One of the dilemmas of large corporations is that of strategic or corporate governance. This dilemma can even exist in smaller organisations whenever there are management responsibilities that are shared by a central decision-making entity and decentralised entities.

The dilemma is based on a lack of clarity in respect of the regulating principles between these entities. The word governance was derived from the word governor which is defined as the individual that governs an area, or the engineering word governor which is a mechanism that measures performance and regulates it within certain levels.

It is proposed that corporate governance be based on two dimensions namely (Moll:14):

- The level of governance based on a continuum between strategic governance and operational governance; and 
- the governance activity based on the continuum between planning, where the governor takes the leading role and governance occurs before the actual activity, and control, where the entity that is being governed takes the leading role and governance occurs after the actual activity.

These dimensions are shown in figure 5.

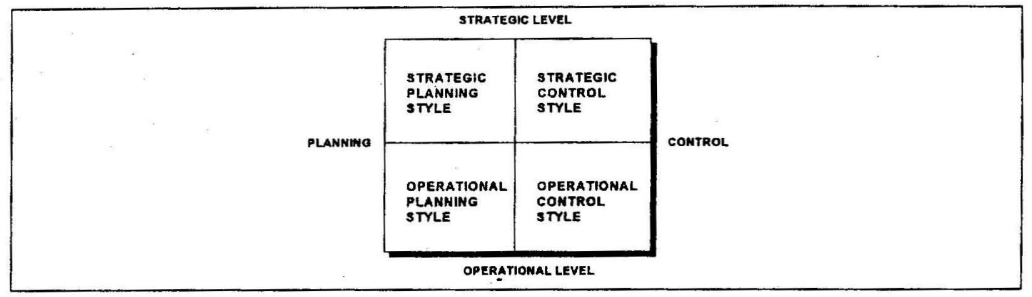

Figure 5 - The dimensions of corporate governance

From these two dimensions, four generic governance styles can be determined. These are:

- A strategic planning governance style where the governor is prescriptive in respect of the strategic direction and leaves the rest to the entity that is being governed;

- a strategic control governance style where the governor expects certain specified : strategic targets to be achieved and leaves the rest to the entity that is being governed;

- an operational planning governance style where the governor is prescriptive in respect of the short-term activities that are being undertaken; and

- an operational control governance style where the governor expects certain specified short-term targets to be achieved.

\section{$5 \quad$ Results}

\subsection{Analysis}

The current status of strategic management within the organisation was analysed. The following conclusions were drawn from this investigation:

- Various elements of strategic management existed within the organisation but a lack of integration and a reactive mode towards strategic management inhibited the contribution that could be made through strategic management.

- Because of the long life cycles that are encountered within the mining industry, longterm planning and strategy was imperative. Because of this, a comprehensive longterm planning process existed in the organisation. This process however, was largely 
based on the planning and budgeting skills in the organisation rather than strategic thinking. Because of this, a need existed to create an environment conducive to strategic thinking.

- Strategic thinking in the organisation ranged from a way of going about their business for some individuals, to quarterly sessions that were held where everything from the external environment, to the current performance of the organisation were discussed.

- A process of Continuous Improvement was being established in the organisation in parallel to the establishment of the strategic management process. It was a necessity not only to integrate the elements of the strategic management process mutually, but also to integrate these with tactical and operational processes, which were largely based on the Continuous Improvement process.

- An important link between Strategic Management and Operations Management was established prior to the investigation though the establishment of a performance management process in the organisation.

- Due to the size of the organisation, a great deal of confusion existed between the corporate centre, the business units and the various mines as to what their specific responsibilities regarding strategic management were.

From these, the following requirements were set for the strategic management process:

- The process should be tolerant for the existing culture and structure of the organisation.

- The process should integrate strategic, tactical and operational processes within the organisation.

- Unnecessary complexity should be avoided in the process. The process must facilitate strategic thinking and the planning element should not become the master of the organisation.

- Sufficient attention should be given to long-range thinking and industry foresight.

\subsection{Design}

By using the Business Engineering Process as a template, the following phases were identified for the strategic management process:

- An analysis phase where the environment of the organisation is investigated in terms of the external, business and internal environments;

- a design phase where the long-term and short-term strategies are defined in relation to this environment;

- a transformation phase where the strategic initiatives that were identified, are implemented; 
- an operational phase where the strategy is executed and operations are continuously improved; and

- a feedback loop from the operational phase back to the analysis phase.

This template, based on the Business Engineering Process is shown in figure 6 .

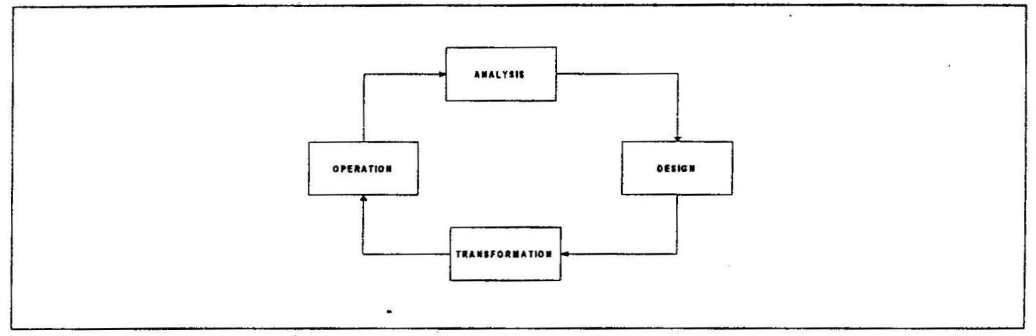

Figure 6 - The Business Engineering template for strategic management

\subsubsection{The analysis phase of strategic management}

The analysis phase of strategic management (also known as scanning) is concerned with a study of trends in the external, business and internal environments.

(a) Scanning the external environment

In order to enable the organisation to study its external environment, three approaches could be followed. These are:

- A single point forecasting process of external parameters such as economic variables, stakeholder requirements and the like;

- a process of qualitative assessment of the various external drivers such as politics, society, economics, technology, global factors and ecology; or

- a scenario planning (Schwartz: 30) process that incorporates qualitative and quantitative methods.

It was suggested that the scenario planning process be implemented because of its ability to develop multiple outcomes of the future, especially because, in most instances, single point forecasting leads to one strategy with one set of parameters. Any external disturbance nullifies such a strategy. 
(b) Scanning the business environment

In order to scan the business environment, it was suggested that a stakeholder view be taken of the organisation through the use of the balanced scorecard (Kaplan and Norton: $[5,16,17)$ methodology. The application of this methodology lead to the following perspectives being established within the organisation:

- The customer perspective;

- the shareholder perspective;

- the innovation and growth perspective; and

- the internal perspective.

(c) Scanning the internal environment

In scanning the internal environment, two processes were recommended:

- A self-assessment process (SWOT-analysis) to be conducted by the management team in quarterly review sessions; and

- feedback relating to current performance as defined by the continuous improvement process.

\subsubsection{The design phase of strategic management}

The proposed design phase of the strategic management process consisted of the following components:

- A long-term strategy;

- long-term objectives; and

- long-term planning.

(a) Long-term strategy

Within this framework, long-term was defined as a period of ten years. The long-term strategy of the organisation is based on an assessment of the current reality of the organisation, its long-term intent and the key initiatives required to reach this long-term intent.

\section{(b) Long-term objectives}

The long-term objectives of the organisation are a quantification of the targets that the organisation sets for itself in respect of performance on the long-term. 
(c) Eong-term planning

The proposed long-term planning process of the organisation is a synthesis of all the plans and budgets that decompose the initial long-term objectives into realistic targets over the ten year period.

\subsubsection{The transformation phase of strategic management}

The proposed transformation phase of the strategic management process consisted of the following components:

- A short-term strategy;

- short-term objectives (targets); and

- short-term planning.

These elements were similar in nature to those defined in the design phase over a ten year period but were the one year version. A detailed discussion is not presented here due to this reason.

\subsubsection{The operational phase of strategic management}

The proposed operational phase of the strategic management process consisted of the following components:

- execution of the proposed strategies; and

- performance review-as feedback back to the design phase.

These were largely based on the proposed continuous improvement process. 


\subsubsection{The proposed strategic management process}

\section{(a) Overall process}

The overall process that was proposed is shown in figure 7 .

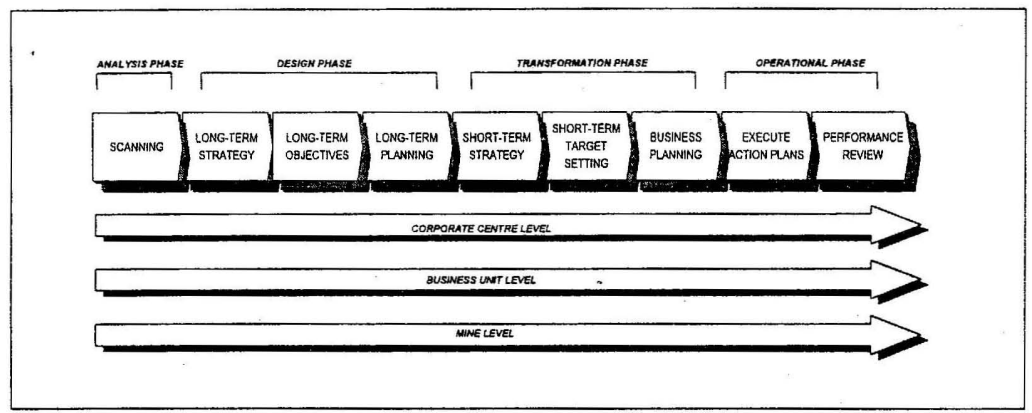

Figure 7 - Proposed strategic management process

It was suggested that this process be repeated in annual cycles that were synchronised with the financial year. A detailed schedule of activities was therefore compiled. 
(b) Strategic governance issues

Due to the complexity of the corporate environment, it was necessary to define the roles of the various organisational levels within the proposed process. These are shown in table 2.

\begin{tabular}{|c|c|c|c|}
\hline ACTIVITY & $\begin{array}{l}\text { CORPORATE } \\
\text { CENTRE }\end{array}$ & $\begin{array}{l}\text { BUSINESS UNIT } \\
\text { LEVEL }\end{array}$ & MINE LEVEL \\
\hline SCANNING & $\begin{array}{l}\text { facilitate scenario } \\
\text { planning process }\end{array}$ & $\begin{array}{l}\text { analyse business } \\
\text { environment }\end{array}$ & $\begin{array}{l}\text { provide input into } \\
\text { SWOT analysis }\end{array}$ \\
\hline $\begin{array}{l}\text { LONG-TERM } \\
\text { STRATEGY }\end{array}$ & $\begin{array}{l}\text { define long-term } \\
\text { strategy }\end{array}$ & $\begin{array}{l}\text { provide input into } \\
\text { long-term strategy }\end{array}$ & $\begin{array}{l}\text { derive own long-term } \\
\text { requirements from } \\
\text { long-term strategy }\end{array}$ \\
\hline $\begin{array}{l}\text { LONG-TERM } \\
\text { OBJECTIVES }\end{array}$ & $\begin{array}{l}\text { define long-term } \\
\text { aspirations }\end{array}$ & test realities & test realities \\
\hline $\begin{array}{l}\text { LONG-TERM } \\
\text { PLANNING }\end{array}$ & $\begin{array}{l}\text { collate long-term } \\
\text { plans }\end{array}$ & $\begin{array}{l}\text { develop long-term } \\
\text { plans for business } \\
\text { units }\end{array}$ & $\begin{array}{l}\text { provide input into } \\
\text { long-term planning } \\
\text { process }\end{array}$ \\
\hline $\begin{array}{l}\text { SHORT-TERM } \\
\text { STRATEGY }\end{array}$ & $\begin{array}{l}\text { define key initiatives } \\
\text { and focus areas on } \\
\text { the short-term }\end{array}$ & $\begin{array}{l}\text { implement key } \\
\text { initiatives }\end{array}$ & $\begin{array}{l}\text { implement key } \\
\text { initiatives }\end{array}$ \\
\hline $\begin{array}{l}\text { SHORT-TERM } \\
\text { TARGET SETTING }\end{array}$ & $\begin{array}{l}\text { approve short-term } \\
\text { targets }\end{array}$ & $\begin{array}{l}\text { define short-term } \\
\text { targets }\end{array}$ & $\begin{array}{l}\text { provide input based. } \\
\text { on practical } \\
\text { implications of short- } \\
\text { term targets. }\end{array}$ \\
\hline $\begin{array}{l}\text { BUSINESS } \\
\text { PLANNING }\end{array}$ & $\begin{array}{l}\text { set budget guidelines } \\
\text { and approve budgets }\end{array}$ & $\begin{array}{l}\text { compile business unit } \\
\text { budgets }\end{array}$ & $\begin{array}{l}\text { compile mine plans } \\
\text { and budgets }\end{array}$ \\
\hline EXECUTION & manage by exception & manage operations & operate the business \\
\hline $\begin{array}{l}\text { PERFORMANCE } \\
\text { REVIEW }\end{array}$ & $\begin{array}{l}\text { decide on corrective } \\
\text { actions where } \\
\text { required }\end{array}$ & $\begin{array}{l}\text { manage operational } \\
\text { performance }\end{array}$ & $\begin{array}{l}\text { measure operational } \\
\text { performance }\end{array}$ \\
\hline
\end{tabular}

Table 2 -Strategic governance structure

\section{Conclusions}

This article used the case study of a large South African Mining company to illustrate how the Business Engineering approach, combined with Strategic Management Theory, can be used to develop a strategic management process. The proposed process is specific - it caters for the requirements set by the specific organisation. The authors believe that the subject area of Strategic Management has become extremely important in the South African context because of various factors that influence the business environment in the country. It is hoped that the proposed approach will, in some way contribute to new insights on the approach required for the strategic management of South African organisations. 
1. ACKOFF, R.L., 1974. Redesigning the Future. John Wiley \& Sons.

2. ACKOFF, R.L., 1981.Creating the corporate future. John Wiley \& Sons.

3. ANSOFF, I., 1965. Corporate strategy. MeGraw-Hill.

4. ANSOFF, I., 1985. Implanting strategic management. McGraw-Hill

5. APPLETON, D.S. 1994. The Principles of Business Engineering. D Appleton Company Inc.

6. CAMP, R.C., 1989. Benchmarking - The search for Industry Best Practices that Leads to Superior Performance. ASQC Quality Press.

7. CAMP, R.C., 1995. Business Process Benchmarking - Finding and Implementing Best Practices. ASQC Quality Press.

8. DAVENPORT, T.H. 1993. Process Innovation: Reengineering Work through Information Technology. Harvard Business School Press.

9. DAVENPORT, T.H., SHORT, J.E. 1990. The New Industrial Engineering: Information Technology and Business Process Redesign. Sloan Management Review. Summer 1990.

10. GOLDRATT, E.M., 1994. It's Not Luck. North River Press.

11. GOLDRATT, E.M., COX, J., 1992. The Goal: A process of ongoing improvement. North River Press.

12. HAMMER, M, CHAMPY, J. 1993. Reengineering the Corporation: A Manifesto for Business Revolution. Nicholas Brealey Publishing Ltd.

13. HAMMER; M., STANTON, S.A., 1995. The Reengineering Revolution. Harper Collins Publishers Inc.

14. JURAN, J.M., 1979. Quality Control Handbook. McGraw-Hill.

15. KAPLAN, R.S., NORTON, D.P., 1993. Putting the Balanced Scorecard to work, Harvard Business Review, September-October 1993.

16. KAPLAN, R.S., NORTON, D.P., 1993. The Balanced Scorecard-Measuring Corporate Performance, Harvard Business School Management Productions.

17. KAPLAN, R.S., NORTON, D.P., 1995. The Balanced Scorecard - Translating Strategy into action. Harvard Business School Press.

18. MANNING, A.D., 1997. Radical strategy. Zebra Press.

19. MINTZBERG, H., 1994. The rise and fall of strategic planning. Free Press.

20. MINTZBERG, H., 1994. The rise and fall of strategic planning. Harvard Business Review. January-February 1994.

21. MINTZBERG, H., QUINN, J.B., 1996. The Strategy Process. Prentice-Hall Inc.

22. MOLL, C.M., 1998. An Engineering approach to Business Transformation. Unpublished PhD-thesis. University of Pretoria

23. MOLL, C.M., BOSMAN, S., 1993. Principles of Business Engineering. Proceedings of Industrial Engineering Conference.

24. PORTER, M.E., 1980. Competitive Strategy - Techniques for Analysing Industries and Competitors. Free Press 
25. PORTER, M.E., 1985. Competitive Advantage - Creating and Sustaining Superior Performance. Free Press.

26. PORTER, M.E., 1990. The Competitive Advantage of Nations. Harvard Business Review. March-April 1990.

27. PRAHALAD, C.K., HAMEL, G., 1989. Strategic Intent. Harvard Business Review. May-June 1989.

28. PRAHALAD, C.K., HAMEL, G., 1990. The Core Competence of the Corporation. Harvard Business Review. May-June 1990.

29. PRAHALAD, C.K., HAMEL, G., 1995. Competing for the Future. Harvard Business School Press.

30. SCHWARTZ, P., 1991. The Art of the Long View. Doubleday Currency.

31. SUN TZU, 1963. The Art of War. Translated by S.B. Griffith.Oxford University Press.

32. SUNTER, C., 1996. The High Road: where are we now? Tafelberg.

33. TREACY, M., WIERSEMA, F., 1993. Customer intimacy and other value disciplines. Harväd Business Review. January-February 1993.

34. TREACY, M., WIESEMA, F., 1995. The Discipline of Market Leaders. AddisonWesley. 